\title{
Kinetics Coefficient of Palm Oil Clinker Media for an Attached Growth Media in Sequencing Batch Reactor Mode
}

\author{
Yap Zhi Kuan', Shamsul R.M. Kutty', Aiban A.S. Ghaleb ${ }^{1 *}$ \\ 1 Department of Civil and Environmental Engineering, Universiti Teknologi PETRONAS, 32610 Seri Iskandar, \\ Perak Darul Ridzuan, Malaysia \\ *Corresponding author's e-mail: aiban_17004546@utp.edu.my
}

\begin{abstract}
Palm oil clinker media (POCM), which is a by-product of incineration process from palm oil industry, creates environmental sustainability issues. This is due to the method of handling solid waste material of industry by simply dumping it on an open land area. The previous study of POCM including physical and mechanical properties of solid present showed promising results of utilizing POCM as a packing media for treatment of domestic wastewater industry. The packing media can be used in the process of biological wastewater treatment system in Sequencing Batch Reactor (SBR) mode. By adopting POCM as an attached growth media, this research paper focuses on the performance of POCM in SBR mode in the context of organic and nutrient removal rate. The performance pertaining to the removal of organics and nutrient was measured using USEPA Standard Method for Chemical Oxygen Demand (COD) and Ammonia. The average rate of removal for COD and Ammonia per biomass adopting POCM in sequencing batch reactor mode is $0.0069 \mathrm{mg}$ COD/mg MLVSS and $0.001 \mathrm{mg}$ Ammonia/mg MLVSS.
\end{abstract}

Keywords:. attached growth media; kinetics coefficient; palm oil clinker; rate of removal; sequencing batch reactor

\section{INTRODUCTION}

Malaysia, which is one of the world largest palm oil manufacturers in the world, produces millions of tons of palm oil by-products yearly. During the 3rd Kuala Lumpur International Conference on Biomedical Engineering, based on research data it was concluded that about 40 million tons of oil palm biomass were produced from the industry alone. This biomass includes empty fruit bunches (EFB), oil palm trunks (OPT), oil palm fronds (OPF) and palm kernel shells (PKS). Traditionally, the biomass wastes are burnt down by the mills or disposed of at the waste pond. However, with the Environmental Quality Act 1974, open field and pile burning are no longer allowed to treat the disposal biomass. Hence, the biomass undergoes combustion process in the steam boiler to generate electricity back to the plant. The byproduct generated from the combustion process which we called palm oil clinker (POC) is a solid, black waste material, presented in Figure 1.1.
The ideal situation of sustainable waste management is to reduce and recycle the waste material or recover energy from the waste. In Malaysia, which is one of the leading producers of palm oil industry, the palm oil production chain produces an abundance of by-products which are believed to be up to almost five times the palm oil production (Abdullah \& Sulaiman, 2013). These had created a sustainability issue regarding the disposal of palm oil by-products. Studies demonstrated that palm oil clinker has great potential to be used as attached growth media in wastewater treatment system. In this research, the kinetics of wastewater parameter removal is determined through the rate of removal of Chemical Oxygen Demand and Ammonia from the laboratory scale sequencing batch reactor constituting a wastewater treatment system.

The objectives of this research study were: (1) To determine the removal of chemical oxygen demand and ammonia using palm oil clinker media as attached growth media in sequencing 


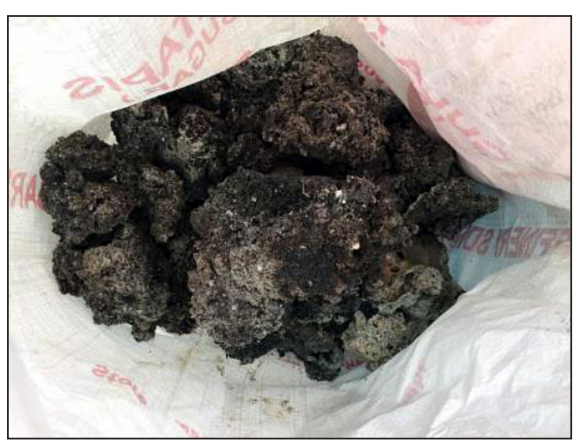

Figure 1. Chunks of POC

batch reactor mode; (2) To determine the kinetics coefficient of organics and nutrients in terms of chemical oxygen demand and ammonia parameter in batch sequence.

\section{LITERATURE REVIEW}

\section{Oil palm by-product}

According to Abdullah and Sulaiman, 2013, palm oil needs to be processed from the fresh fruit bunches through a series of actions. First, the fresh fruit bunches of palm oil are be collected and sent to palm oil mill for the production process. The fresh fruit bunches undergo sterilization and stripping to become fresh fruits before transport into digester. In the digester, a large volume of water with the temperature of 80 to 90 degrees Celsius is added and pressed against in the digester. After a series of processes, the palm oil and palm kernel oil are produced, which are ready to be stored or processed for export. Apart from the palm oil and palm kernel oil, there are lots of by-products that are generated throughout the oil extraction process. These by-products include empty fruit bunches, fibre and shells etc. In the early stage of palm oil industry, these by-products were considered waste material and were burned openly to dispose of. However, Environmental Quality Act 1974 had restricted the open burning of waste material practice in the palm oil industry due to the air pollution. Since then, the byproducts were sent into a steam boiler to generate electricity and supply the oil palm mill. A general study had concluded that a standard size palm oil mill is capable of processing 60 tons of fresh fruit bunches per hour and 40 tons of steam per hour. Partial amount of the produced steam is used as source to generate 800 kilowatts of electricity for the mills, while the rest remains as process gas.
The incineration process of palm oil by-product in the steam boiler leaves a solid, blackish residue. The blackish residue is the targeted material in this research study, i.e. palm oil clinker (POC). POC is a solid waste material which is black in colour. This material is a relatively new and interesting material to be used in the recent development of lightweight concrete by replacing the aggregates or fly ash (Ahmad, Hilton, \& Mohd Noor, 2007; Ahmad, Hilton, Mohd, \& Mohd Noor, 2007). The raw POC material after the combustion process can be obtained in chunks of sizes between 100 to $500 \mathrm{~mm}$ (Kanadasan, Razak, \& Design, 2014). An observation study was conducted on the POC which contained a huge number of voids and pores, rough surface and irregular shape. POC is considered a stable and non-biodegradable material with the chemical composition mixture of $\mathrm{SiO}_{2}, \mathrm{Al}_{2} \mathrm{O}_{3}$ and $\mathrm{Fe}_{2} \mathrm{O}_{3}$ (Karim et al., 2016).

\section{Aerobic biological oxidation}

Aerobic biological oxidation occurs when the conversion of organic matter takes place by mixed microorganism cultures. With sufficient oxygen, aerobic biological decomposition is carried out until organic waste runs out. In the process, three reactions occur, represented by equation below.

Firstly, oxidation process occurs, the Carbon, Oxygen, Hydrogen, Nitrogen, and Sulphur (COHNS) elements found in the waste are oxidized to produce energy for cell maintenance and cell synthesis. Secondly, synthesis reaction of COHNS to new cell occurs by using the energy produced from oxidation. Lastly, when COHNS are insufficient, the microorganism undergoes endogenous respiration by consuming own cell tissue for energy production (Tchobanoglous et al., 2014). The classification of microorganism that promotes the biomass growth consists of a few types of bacteria such as aerobic heterotrophic and aerobic autotrophic bacteria. The characteristic of the two types of bacteria are shown as Table 1.

Oxidation.

$$
\begin{aligned}
& \text { COHNS }+\mathrm{O}_{2}+\text { bacteria }+ \text { energy } \rightarrow \\
& \rightarrow \mathrm{CO}_{2}+\mathrm{H}_{2} \mathrm{O}+\mathrm{NH}_{3}+\text { energy }
\end{aligned}
$$

Synthesis.

$$
\begin{aligned}
& \text { COHNS }+\mathrm{O}_{2}+\text { bacteria }+ \text { energy } \rightarrow \\
& \rightarrow \mathrm{C}_{5} \mathrm{H}_{7} \mathrm{NO}_{2} \text { (new cell tissue) }
\end{aligned}
$$

Endogenous Respiration.

$$
\mathrm{C}_{5} \mathrm{H}_{7} \mathrm{NO}_{2}+5 \mathrm{O}_{2} \rightarrow 5 \mathrm{CO}_{2}+2 \mathrm{H}_{2} \mathrm{O}+\mathrm{NH}_{3}
$$




\section{Packing media model}

The selection of suitable packing media should be characterized by rapid and stable attachment between biomass and surface area of the packing media. The surface area of packing media determines the area available for bacterial growth while the porosity of packing media determines the clogging issues and available biofilm thickness (Nguyen, Ngo, Guo, Johnston, \& Listowski, 2009). The packing media should meet a few criteria which include high specific surface area, high porosity and void ratio, durability and affordable cost. A packing media should be able to allow continuous sloughing of bacteria to reduce the clogging issues, as well as allow maximum ventilation and surface area for contact with wastewater (Ward \& Watt, 1962). The aerobic microorganism is responsible for degrading the organics present in the wastewater that flows through the packing media. The size of packing media affects the submerged attached growth process regarding the surface area available per unit of reactor volume for microorganism growth and substrates removal rates. (Moore, Quarmby, Stephenson, \& Protection, 1999).

Numerous studies on the packing media for attached growth system were conducted in the past. Different types of packing media such as square ring polypropylene media $(60 \mathrm{~mm}$ in diameter), pall rings of $25 \mathrm{~mm}$ to $38 \mathrm{~mm}$, cylindrical ring supports the media of open-pored surface texture glass material and smooth surface PVC
Raschig (25 mm diameter) rings (Cortez, Teixeira, Oliveira, Mota, \& Bio/Technology, 2008; Mathure \& Patwardhan, 2005; Nahid, Vossoughi, \& Alemzadeh, 2001; Rodgers, Zhan, \& Biotechnology, 2003; Show \& Tay, 1999; Sirianuntapiboon, 2006; Tay, Show, \& Jeyaseelan, 1996). Pumice, a light and porous volcanic rock was utilised as a packing media due to its properties of high porosity, large surface area and low cost of material (Borghei, Sharbatmaleki, Pourrezaie, \& Borghei, 2008). Oxidation process occured, the waste containing Carbon, Oxygen, Hydrogen, Nitrogen, and Sulphur (COHNS) elements was oxidized to produce energy for cell maintenance and cell synthesis. Secondly, the synthesis reaction of COHNS to new cell occurred by using the energy produced from oxidation. Lastly, when COHNS are insufficient, the microorganism undergo endogenous respiration by consuming own cell tissue for energy production (Tchobanoglous et al., 2014).

\section{METHODS}

\section{Media preparation}

In order to understand and obtaine the raw palm oil clinker, the sample was collected directly from Kilang Sawit Felcra Berhad, Seberang Perak. All the clinker gathered was crushed into smaller pieces and dried in the oven. After drying, the clinker went through selective sieving process to obtain a nominal size between $25 \mathrm{~mm}$ to $35 \mathrm{~mm}$.

Table 1. Classification of heterotrophic and autotrophic aerobic microorganism

\begin{tabular}{|c|c|c|c|c|c|}
\hline Bacteria & Reaction & Carbon source & Electron donor & Electron acceptor & Products \\
\hline $\begin{array}{c}\text { Aerobic } \\
\text { Heterotrophic }\end{array}$ & Aerobic Oxidation & $\begin{array}{c}\text { Organic } \\
\text { Compound }\end{array}$ & $\begin{array}{c}\text { Organic } \\
\text { Compound }\end{array}$ & Oxygen & $\begin{array}{c}\text { Carbon Dioxide, } \\
\text { Water }\end{array}$ \\
\hline Aerobic Autotrophic & Nitrification & Carbon Dioxide & $\begin{array}{c}\text { Ammonium, } \\
\text { Nitrite }\end{array}$ & Oxygen & Nitrite, Nitrate \\
\hline
\end{tabular}

Table 2. Previous packing media model

\begin{tabular}{|l|l|}
\hline \multicolumn{1}{|c|}{ Researcher } & \multicolumn{1}{c|}{ Research model } \\
\hline Borghei, Sharbatmaleki, Pourrezaie, \& Borghei (2008) & Pumice (volcanic rock) \\
\hline Cortez, Teixeira, Oliveira, Mota, \& Bio/Technology (2008) & 60mm square polypropylene ring media \\
\hline Mathure \& Patwardhan (2005) & PVC pall rings media of $25 \mathrm{~mm}$ to $35 \mathrm{~mm}$ \\
\hline Show \& Tay (1999) & $\begin{array}{l}\text { Open pores glass material cylindrical ring } \\
\text { support media } 25 \mathrm{~mm}\end{array}$ \\
\hline Show \& Tay (1999) & Smooth surface PVC Raschig ring $25 \mathrm{~mm}$ \\
\hline Sirianuntapiboon (2006) & Cube plastic tubes of 8 $\mathrm{mm}^{3}$ \\
\hline
\end{tabular}




\section{Reactor setup}

The experiment was conducted using lab scale reactor made of $5 \mathrm{~mm}$ thick Perspex rectangular box shape reactor. The flow schematic diagram of experimental setup was shown in Figure 3 below. The Reactor A acts as a control reactor that adopts the biological treatment process of sequencing batch reactor mode without palm oil clinker as attached growth media. For Reactor B, the palm oil clinker was added as a packing media for sequencing batch reactor mode to evaluate the efficiency of organics removal. Air diffuser was added at the bottom of reactor to create an aerobic condition for the oxidation and nitrification process to take place (Lee, Ahn, \& Lee, 2000). The reactor was on an acclimatization period of about 3 to 4 weeks for the microorganism to adjust and maintain a steady performance in the environment. The steady performance of reactor can be represented by the result of effluent COD and Ammonia measurements. The influent and effluent sample was collected once every two days for the measurement of COD and Ammonia. The feeding flow rate of wastewater was about $1.6 \mathrm{~L} /$ hour from the STP in UTP and hydraulic detention time of 2 days.

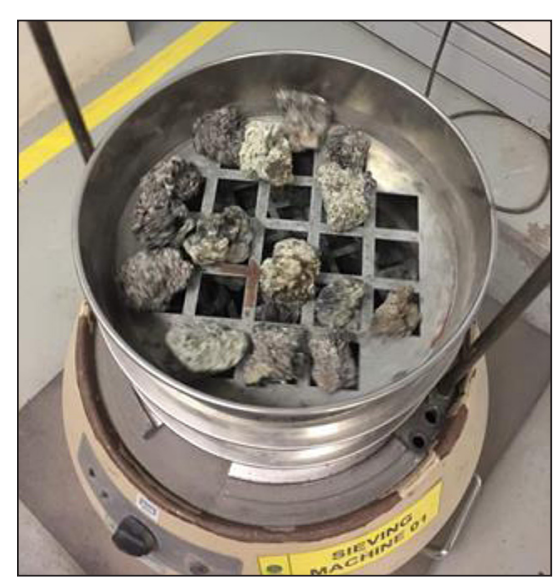

Figure 2. Selective sieving of clinker

\section{Sequencing batch reactor}

The laboratory scale SBR was constructed using $5 \mathrm{~mm}$ thick Perspex plastic sheet obtained by laser cutting and joining. The total volume of reactor was 10L. The air diffusers were installed at the bed of reactor, as shown in the figures below. The air diffuser acted as an aeration system for the treatment process. The air diffuser was to ensure the presence of oxygen in the reactor for the aerobic microorganism to perform oxidation and nitrification. Besides, the air diffuser also acted as a mixing mechanism for the organic matter in the wastewater reactor.

The mechanism of reactor adopts the sequencing batch reactor process design (SBR system). The uniqueness of SBR system lies in the usage of only single tank for both aeration and settling process. The returned activated sludge can be neglected by using SBR system (Tchobanoglous et al., 2014). There is a general operational process for an SBR system reactor which includes filling, reacting, settling, decanting and idling. The filling process occurs during the flow or addition of influent wastewater that fills the reactor tank from $75 \%$ to $100 \%$ of volume storage. During the filling process, aeration and mixing can be applied to aid the biological reaction with raw wastewater. The reactor is then followed with reacting process to promote the biological process for organics and nutrient removal with the help of aeration and mixing. Then, the solution is allowed to settle in the reactor during the settling stage. This is to separate the solids from clarified supernatant and prepared for decanting stages to remove the supernatant as effluent. Lastly, the idle stage is provided for a multi-container system to provide sufficient time before switching to another phase in the SBR system.

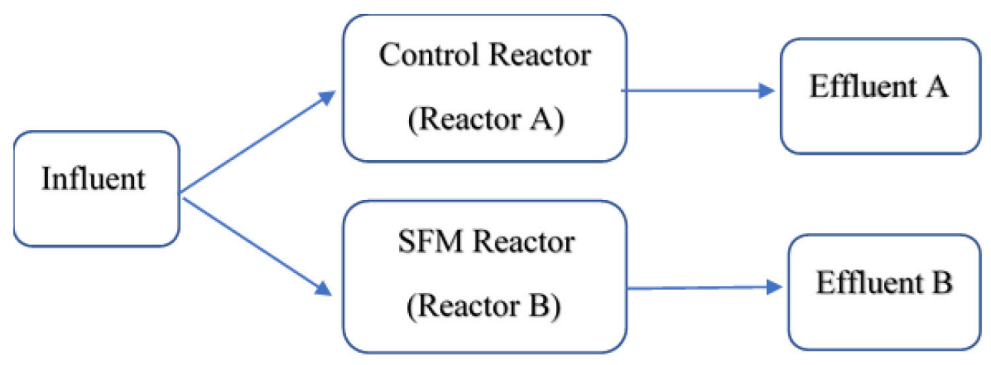

Figure 3. Schematic diagram of experimental setup 


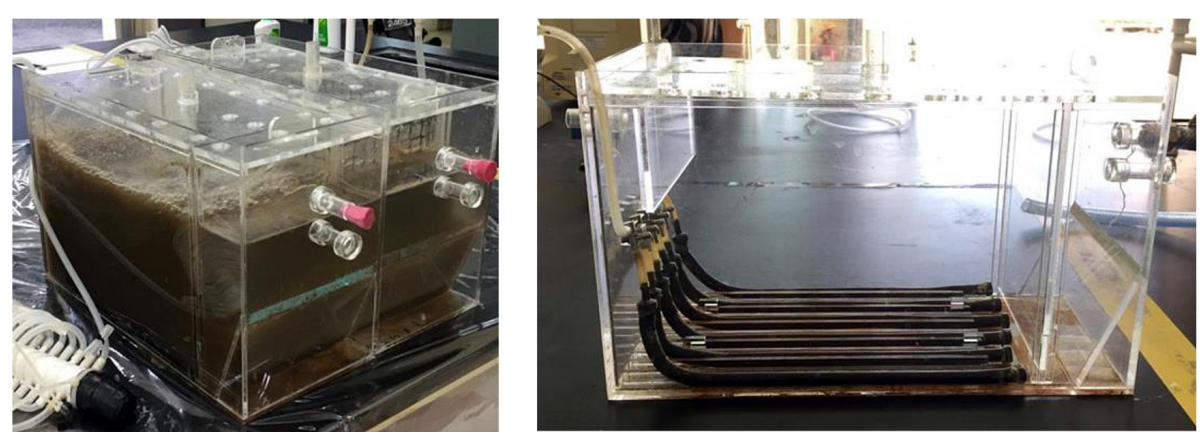

Figure 4. Reactor setup

\section{Sampling measurements}

The COD measurement procedure (Standard Method 5220 D) is approved by USEPA for wastewater analyses. The COD corresponds to the milligrams measurement of oxygen, $\mathrm{O}_{2}$ consumed per litre of sample wastewater. The sample was heated with sulfuric acid and potassium dichromate as oxidizing agent for 2 hours. In the reaction, oxidizable organics reduced dichromate ion $\left(\mathrm{Cr}_{2} \mathrm{O}_{7}^{2-}\right)$ to chromic ion $\left(\mathrm{Cr}^{3+}\right)$. The remaining amount of $\mathrm{Cr}^{6+}$ was measured when 3-150 mg/L colorimetric method was used. When $20-1500 \mathrm{mg} / \mathrm{L}$ of colorimetric method was obtained, the amount of $\mathrm{Cr}^{6+}$ produced was measured. There could have been silver and mercury ions present in the COD reagent as catalyst and interference of complex chloride.

The ammonia measurement procedure (Standard Method 350.2) is approved by USEPA for wastewater analyses. Distillation was required prior to the measurement of sampling. The polyvinyl alcohol dispersing agent aided in the formation of colour in the reaction of Nessler Reagent with ammonia and other amines. The concentration of ammonia was relative to the formation of yellow colour. The HACH measurement wavelength used was $425 \mathrm{~nm}$

\section{RESULTS AND DISCUSSIONS}

\section{Clinker packing media}

After the sieving process, the POC packing media was obtained and then ready to be used as SFM in the SBR mode for wastewater treatment process. The main composition of POC packing media consisted of $\mathrm{Al}_{2} \mathrm{O}_{3}, \mathrm{SiO}_{2}$ and $\mathrm{Fe}_{2} \mathrm{O}_{3}$. The literature review was done to obtain the physical properties of POC such as size, specific gravity, bulk density as shown in Table 3. Some preliminary testing results on the POC packing media and reactor specification were obtained. The POC packing media that had been sieved to desired size were soaked in the influent wastewater obtained from UTP sewerage treatment plant to observe and record the reaction of POC.

\section{Samplingmeasurements}

\section{Mixed liquor suspended solids (MLSS) \& mixed liquor suspended solids (MLVSS) results}

The efficiency of POC as SFM in SBR mode can be represented by the removal of organics in terms of COD and TSS. In order for the removal of organics to achieve the desired capability, the concentration of MLSS for both reactors should be carefully monitored and maintained. The MLSS is the number of suspended solids contained in one litre of mixed liquor while the MLVSS is the number of suspended solids contained in one litre of mixed liquor that is combustible at $550{ }^{\circ} \mathrm{C}$. The MLSS measurement testing adopted the USEPA standard method using Whatman glass microfibre filters of $1.5 \mu \mathrm{m}$

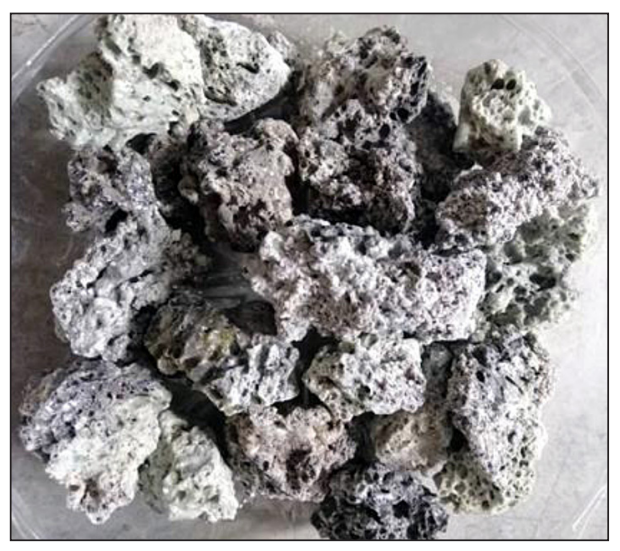

Figure 5. Palm oil clinker media 
Table 3. Properties of palm oil clinker

\begin{tabular}{|l|c|}
\hline Properties & Value \\
\hline Size & $25 \mathrm{~mm}-35 \mathrm{~mm}$ \\
\hline Specific gravity & $1.64-1.80$ \\
\hline Bulk density & $742 \mathrm{~kg} / \mathrm{m}^{3}-782 \mathrm{~kg} / \mathrm{m}^{3}$ \\
\hline
\end{tabular}

pore size, $47 \mathrm{~mm}$ diameter and $435 \mu \mathrm{m}$ thickness. The MLSS and MLVSS concentration results recorded over sampling days are presented in Figure 6 and 7, respectively.

The MLSS and MLVSS concentration are contributed by the biomass inside reactor. The biomass acts as biological treatment for domestic wastewater. The biomass in Reactor A is suspended while Reactor B is suspended and attached on the POC media. The attachment to POC increases the contact surface area for biomass with influent raw wastewater. Hence, the efficiency of treatment and removal are improved. The MLSS for both reactors are targeted to maintain in between 1000 to $1500 \mathrm{mg} / \mathrm{L}$ to achieve a similar and identical condition for comparison of conventional activated sludge reactor and sequencing batch reactor.

However, the results show a reduction of the MLSS value throughout the sampling days. The MLSS value reduces and fluctuates among $600 \mathrm{mg} / \mathrm{L}$ to $900 \mathrm{mg} / \mathrm{L}$ throughout the experiment. The most possible cause of this phenomenon is due to the washout of biomass and the stagnation of biomass within the POC. Throughout the sampling days, a small amount of biomass had been observed to washout together with the effluent. The biomass is observed to be trapped within the space between POC media and could not be well-mixed and suspended during the sampling for MLSS. It is concluded that the performance of SBR for organics removal can be increased with the higher MLSS reading within the aeration tank.

\section{Removal of chemical oxygen demand (COD) result}

The COD test is required to obtain the organic in the wastewater that can be chemically oxidized using dichromate under acidic conditions. The results of COD are commonly used together with biochemical oxygen demand (BOD) results to measure the amount of nonbiodegradable organic substances in wastewater. The COD results achieve a stable reading after a 2 weeks acclimatization period. The overall result of COD managed to achieve the targeted effluent limit of about $20 \mathrm{mg} / \mathrm{L}$ for Reactor B using POC as SFM in SBR mode. On the other hand, the overall COD effluent value of Reactor A without POC was slightly higher at about $40 \mathrm{mg} / \mathrm{L}$ COD and maintain higher than Reactor B throughout the experiment duration. This proved that the usage of POC as SFM in SBR mode helps in improving the effluent quality of wastewater treatment.

The COD results of influent wastewater fluctuate gradually in the early days of sampling. The addition of cat food was done to increase the COD value in the influent on sampling day 15 . Hence, the graph of influent COD reaches a peak of $100 \mathrm{mg} / \mathrm{L}$ COD. For the first few samplings of effluent COD, the value is unexpectedly high to reach about $70 \mathrm{mg} / \mathrm{L}$ and $50 \mathrm{mg} / \mathrm{L}$ for reactors $\mathrm{A}$ and $\mathrm{B}$, respectively. It is believed that the biomass washed out together into the effluent during the decanting stage gives rise to the effluent COD. After increasing the settling period from 30 minutes to 240 minutes, the effluent seems to be reduced drastically to a range of $30 \mathrm{mg} / \mathrm{L}$ COD. It can be concluded that the experimental setup can achieve COD removal of $55 \%$ and $67 \%$ for $\mathrm{Re}$ actor $\mathrm{A}$ and $\mathrm{B}$, respectively.

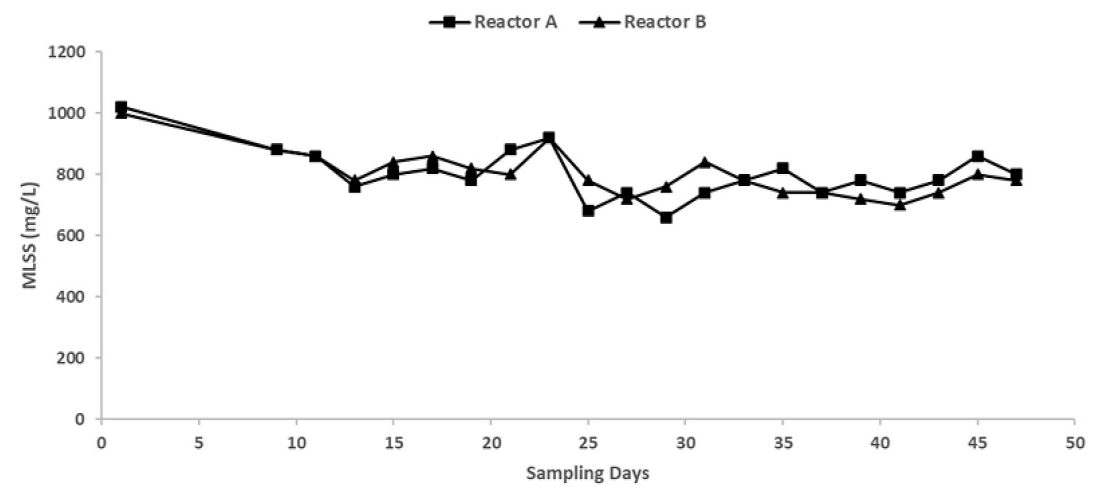

Figure 6. Graph of MLSS vs sampling days 


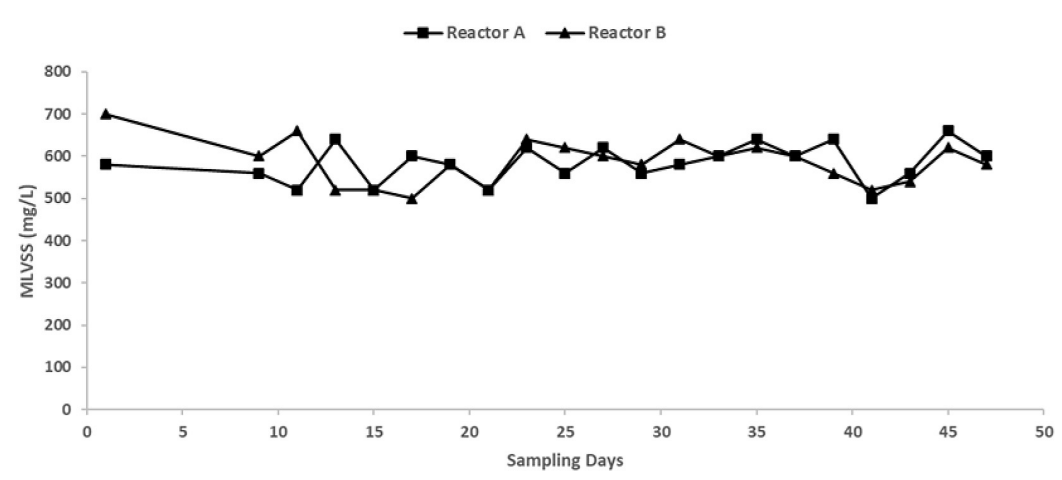

Figure 7. Graph of MLSS vs sampling days

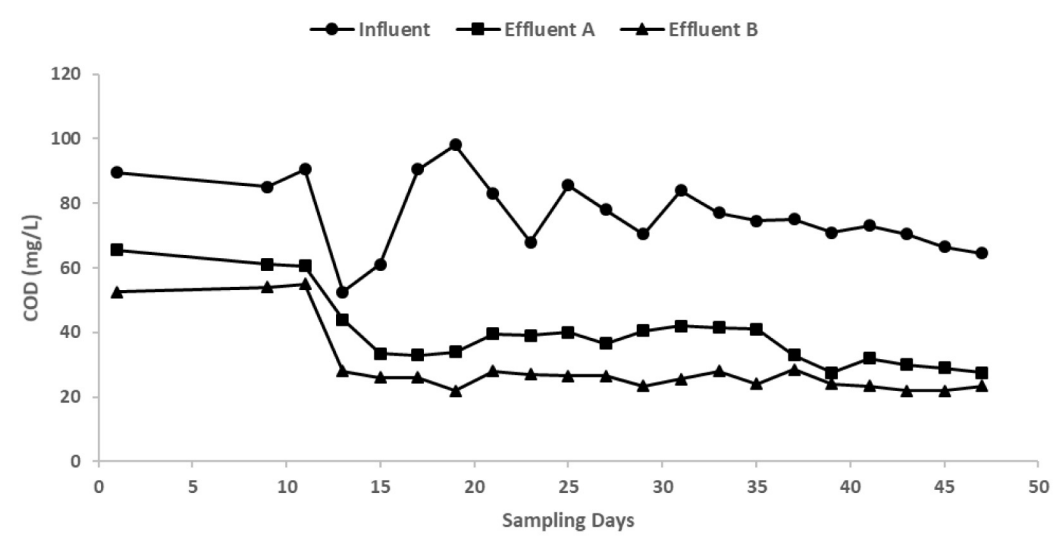

Figure 8. Graph of chemical oxygen demand vs sampling days

\section{Removal of ammonia result}

The ammonia result using the Nessler Method test indicated that higher colour intensity of sampling was present at higher concentration of ammonia nitrogen. The results of ammonia nitrogen are as shown in Figure 10 and 11 for influent and effluent concentration, respectively. The influent of ammonia ranges from 4 to $8 \mathrm{mg} / \mathrm{L}$ and achieve $85 \%$ and $90 \%$ removal for the reactor A and $\mathrm{B}$.

\section{Rate of removal per biomass}

The rates of Chemical Oxygen Demand (COD) removal per biomass for both reactors are calculated by dividing the product of COD removed and influent volume with the product of biomass and reactor volume. The results were obtained from the COD effluent graph after the stabilization period, as shown in Figure 12 and 13.

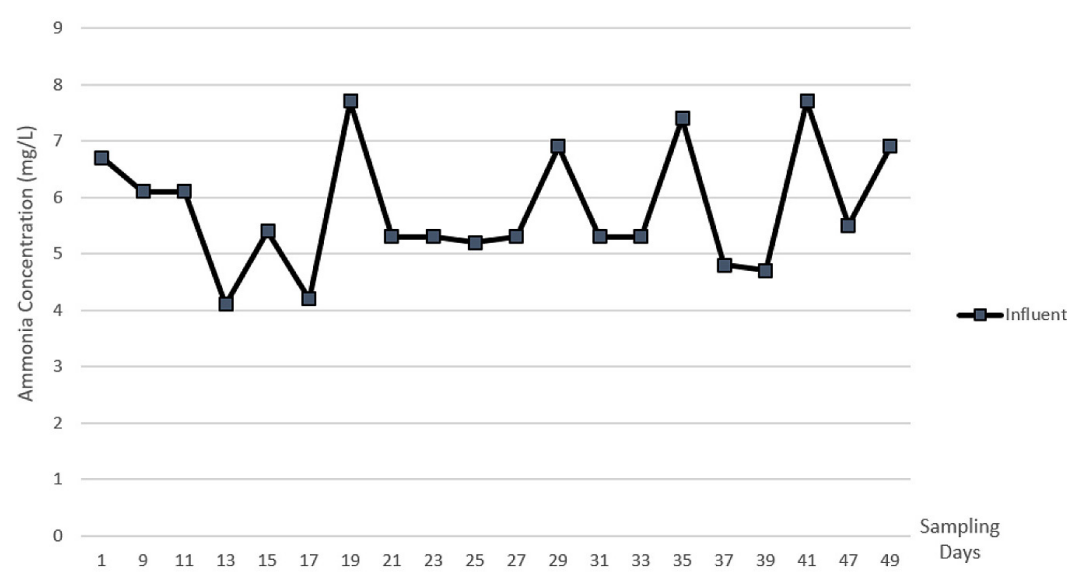

Figure 9. Graph of influent ammonia vs sampling days 


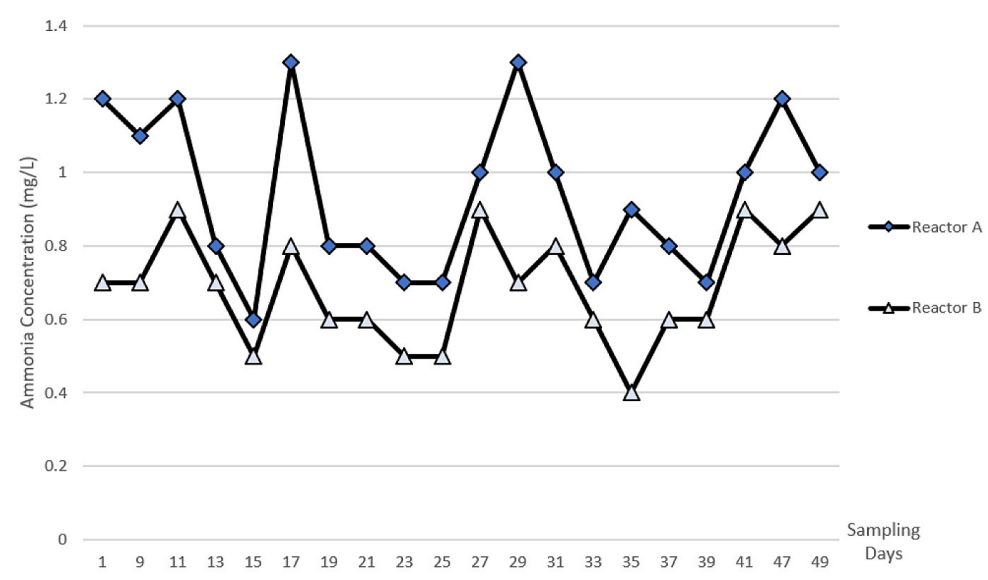

Figure 10. Graph of effluent ammonia vs sampling days

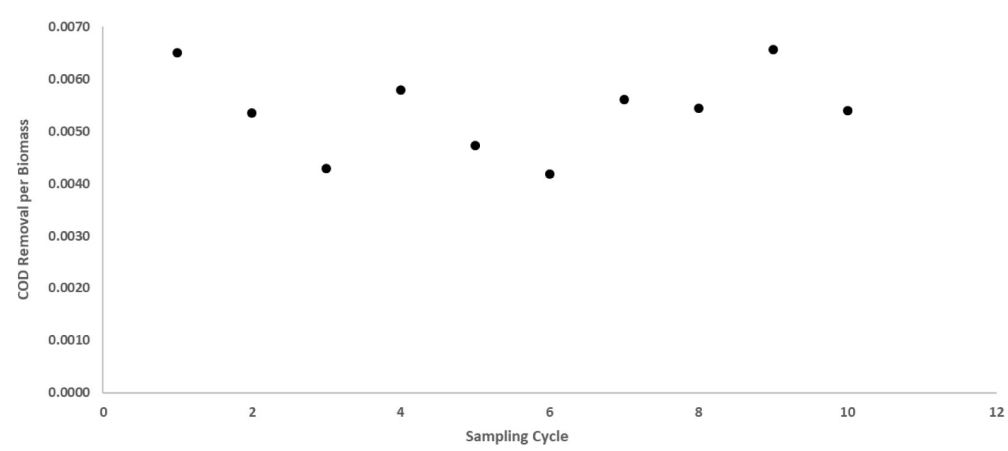

Figure 11. Organics rate of removal per biomass (reactor A)

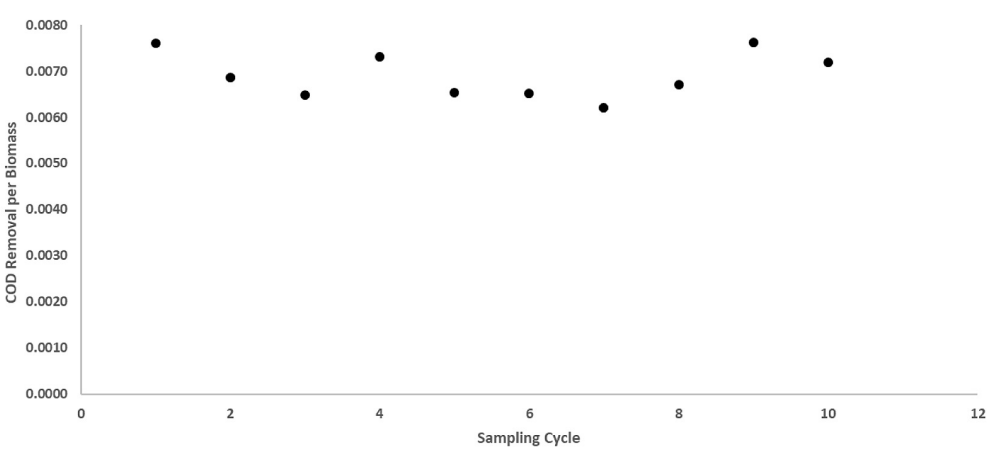

Figure 12. Organics rate of removal per biomass (reactor B)

The results for Reactor A and Reactor B are $0.0054 \mathrm{mg} / \mathrm{L}$ and $0.0069 \mathrm{mg} / \mathrm{L}$ for the rate of removal per biomass. The values here represented how much COD can be removed by a biomass in the reactor. Hence, we can conclude that Reactor B performs more efficiently compared to Reactor A.

As far as the ammonia removal is concerned, the usage of palm oil clinker media in sequencing batch reactor obtained an average kinetics of $0.0007 \mathrm{mg}$ Ammonia / mg MLVSS and 0.001 mg Ammonia / mg MLVSS for reactor A and B respectively. The usage of palm oil clinker media shows better results on the removal rate in reactor $\mathrm{B}$ with the presence of palm oil clinker media, shown in figures below.

\section{CONCLUSIONS}

Concluding from the research report, palm oil clinker - as a waste by-product from boiler plant of oil palm industry - can be utilized as a medium for submerged attached growth wastewater 


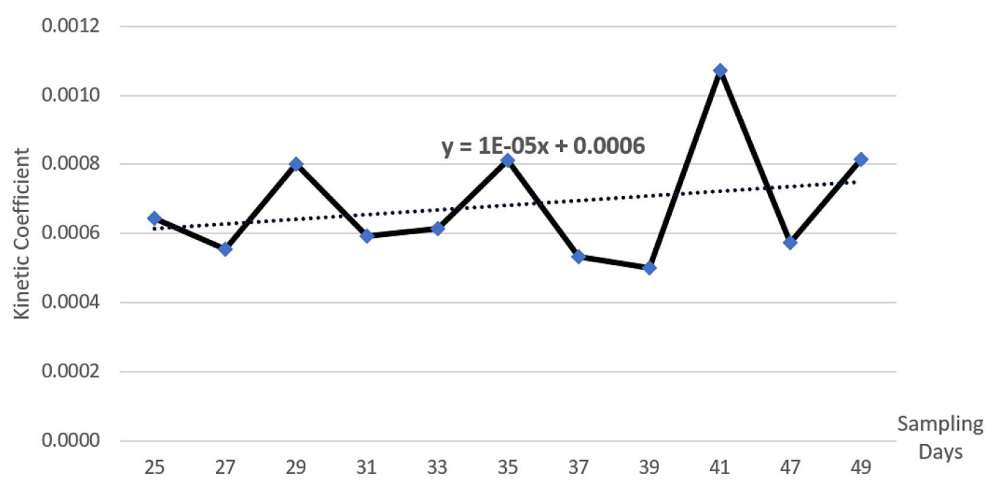

Figure 13. Nutrients rate of removal per biomass (reactor A)

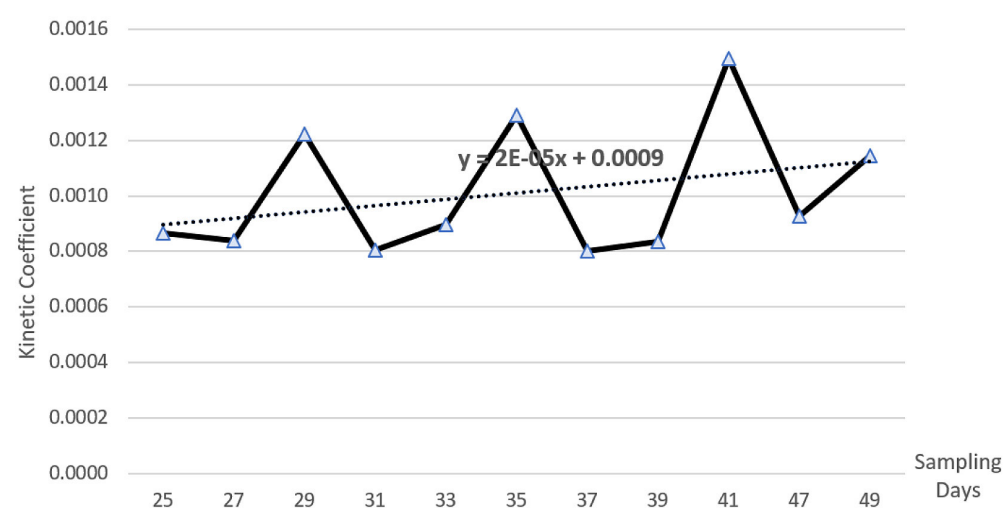

Figure 14. Nutrients rate of removal per biomass (reactor B)

treatment process. The POC acts as a medium for aerobic microorganism for attached-growth process for the organic removal of domestic wastewater from UTP wastewater treatment plant. Removal of organics and nutrients using palm oil clinker media in SBR mode was verified using COD and Ammonia test measurement according to the standard method. The removal efficiency of COD and Ammonia achieved $70 \%$ and $90 \%$ removal, respectively. The POC source provides low cost and simple operation which is said to be more efficient for small communities such as campus, village, and hostel etc. The rate of COD removal per biomass is higher and more stable for Reactor A, compare to Reactor B as per the results calculated from the effluent quality. The kinetics coefficient obtained for organics and nutrients are $0.0069 \mathrm{mg} \mathrm{COD} / \mathrm{mg}$ MLVSS and $0.001 \mathrm{mg} \mathrm{Am-}$ monia / mg MLVSS, respectively.

The experiment can be further enhanced by increasing the testing parameters of effluent and more frequent sampling of effluent for more reliable and accurate result data. Besides, by varying the design parameters such as flow rate, reactor volume and settling time, the operational problem like biomass washout can be minimized and the performance of palm oil clinker media in sequencing batch reactor mode application can be improved.

\section{Acknowledgment}

The authors acknowledge the support of UTP, Malaysia for successful completion of this study.

\section{REFERENCES}

1. Abdullah, N., and Sulaiman, F. (2013). The oil palm wastes in Malaysia. In Biomass Now-Sustainable Growth and Use. InTech.

2. Ahmad, H., Hilton, M., \& Mohd Noor, N. (2007). Physical properties of local palm oil clinker and fly ash.

3. Ahmad, H., Hilton, M., Mohd, S., \& Mohd Noor, N. (2007). Mechanical properties of palm oil clinker concrete.

4. Eaton, A.D., Clesceri, L.S., Rice, E.W., Greenberg, A.E., \& Franson, M.A.H.A. (2005). APHA. standard methods for the examination of water and wastewater. Centennial Edition., APHA, AWWA, WEF, Washington, DC. 
5. Borghei, S., Sharbatmaleki, M., Pourrezaie, P., \& Borghei, G.J.B.T. (2008). Kinetics of organic removal in fixed-bed aerobic biological reactor. 99(5), 1118-1124.

6. Cortez, S., Teixeira, P., Oliveira, R., Mota, M.J.R.I.E.S., \& Bio/Technology. (2008). Rotating biological contactors. a review on main factors affecting performance. 7(2), 155-172.

7. Harrison, J.R., and Daigger, G.T.J.J. (1987). A comparison of trickling filter media. 679-685.Kanadasan, J., Razak, H.A.J.M., \& Design. (2014). Mix design for self-compacting palm oil clinker concrete based on particle packing. 56, 9-19.

8. Karim, M.R., Hashim, H., Razak, H.A., Yusoff, S.J. C., \& Materials, B. (2016). Characterization of palm oil clinker powder for utilization in cement-based applications. 135, 21-29.

9. Lee, J., Ahn, W.-Y., \& Lee, C.-H.J.W.R. (2000). Comparison of the filtration characteristics between attached and suspended growth microorganisms in submerged membrane reactor. 35(10), 2435-2445.

10. Mathure, P., Patwardhan, A.J.J.O.C.T., Biotechnology. International Research in Process, E., \& Technology, C. (2005). Comparison of mass transfer efficiency in horizontal rotating packed beds and rotating biological contactors. 80(4), 413-419.

11. Melin, T., Jefferson, B., Bixio, D., Thoeye, C., De Wilde, W., De Koning, J., Wintgens, T.J.D. (2006). Membrane reactor technology for wastewater treatment and reuse. 187(1-3), 271-282.

12. Moore, R., Quarmby, J., Stephenson, T.J.P.S., \&
Protection, E. (1999). BAF media. ideal properties and their measurement. 77(5), 291-297.

13. Nahid, P., Vossoughi, M., \& Alemzadeh, I.J.P.B. (2001). Treatment of bakers yeast wastewater with a Biopack system. 37(5), 447-451.

14. Nguyen, T.T., Ngo, H.H., Guo, W., Johnston, A., \& Listowski, A.J.B.T. (2009). Effects of sponge size and type on the performance of an up-flow sponge reactor in primary treated sewage effluent treatment. 101(5), 1416-1420.

15. Rodgers, M., Zhan, X.-M.J.R.I.E.S., \& Biotechnology. (2003). Moving-medium biofilm reactors. 2(2-4), 213-224.

16. Show, K.-Y., and Tay, J.-H.J.W.R. (1999). Influence of support media on biomass growth and retention in anaerobic filters. 33(6), 1471-1481.

17. Sirianuntapiboon, S.J.B.T. (2006). Treatment of wastewater containing $\mathrm{Cl} 2$ residue by packed cage rotating biological contactor (RBC) system. 97(14), 1735-1744.

18. Tay, J.-H., Show, K.-Y., \& Jeyaseelan, S.J.J.O.E.E. (1996). Effects of media characteristics on performance of upflow anaerobic packed-bed reactors. 122(6), 469-476.

19. Tchobanoglous, G., Stensel, H., Tsuchihashi, R., Burton, F., Abu-Orf, M., Bowden, G., \& Pfrang, W. (2014). Metcalf and Eddy I AECOM. Wastewater engineering. treatment and resource recovery. In. New York. McGraw-Hill Book Company.

20. Ward, T.D., and Watt, S.M. (1962). Trickling filter media. In: Google Patents. 